\title{
HYPOTHESIS
}

\section{HLA-B27 associated spondyloarthropathy, an autoimmune disease based on crossreactivity between bacteria and HLA-B27?}

\author{
J H Ringrose
}

\begin{abstract}
Most autoimmune diseases are associated with certain HLA types. Therefore, spondyloarthropathies (SpA) strongly associated with HLA-B27, are also often classified as autoimmune diseases. This study questions whether $\mathrm{SpA}$ indeed fulfils the criteria of an autoimmune disease. The Medline database was searched for all reports between 1966 and April 1998 on the presence of autoimmune reactivity in SpA patients. This search yielded 45 articles on this subject. Only eight articles study $T$ cell reactivity. Twelve reports were found on the assessment of antibodies crossreacting between bacteria and HLAB27. In the 45 studies demonstrating autoimmune reactions in $\mathrm{SpA}$ patients proper controls matched for HLA-B27, sex and age were nearly always lacking. Therefore, it is concluded that the frequency of increased autoreactivity in sera from patients and controls is not significantly different, and that this lack of autoreactivity does not justify classification of SpA as an autoimmune disease. As crossreactive antibodies against bacteria and HLA-B27 were equally present in sera from patients and controls, the pathogenetic significance of molecular mimicry between various bacteria and HLA-B27 is questionable. Furthermore, the regions of the B27 molecule that are supposed to be crossreactive with bacteria, differ in one or more amino acids among the distinct B27 subtypes. Although these differences strongly influence the binding of antibodies to the B27 molecule, there was no relation between the degree of crossreactivity of certain subtypes and the association of these subtypes with $\mathrm{SpA}$. In conclusion, there is no evident proof that $\mathrm{SpA}$ is an autoimmune disease attributable to crossreactivity between bacteria and HLA-B27. (Ann Rheum Dis 1999;58:598-610)
\end{abstract}

The spondyloarthropathies ( $\mathrm{SpA})$ are a group of diseases including ankylosing spondylitis (AS), reactive arthritis (ReA), and Reiter's syndrome (RS). ${ }^{1}$ One third of the HLA-B27 posi- tive AS patients has also acute anterior uveitis (AAU), whereas more than half of the HLAB27 positive patients with AAU fulfils the criteria for $\mathrm{SpA}$. A remarkable high association between AS, ReA, RS and AAU and the expression of the MHC class-I molecule HLAB27 is reported. ${ }^{2-6}$

The assumption is often made that B27 associated diseases are autoimmune diseases (AID).$^{7-9}$ Because a number of bacterial species have been associated with the initiation of ReA, and because a high prevalence of Klebsiella pneumonia and of antibodies to Klebsiella in AS patients has been reported, it has been suggested that bacteria play a part in the pathogenesis of B27 associated SpA. ${ }^{7-10}$ The term "molecular mimicry", introduced in 1964, describes the resemblance of antigenic epitopes of microbial constituents and autologous material. ${ }^{11}{ }^{12}$ Molecular mimicry between viral proteins and host cell proteins has been suggested to be one of the causes of AID. ${ }^{13}{ }^{14}$ Therefore, the hypothesis has also been made that molecular mimicry between bacteria and HLA-B27 plays a pathogenetic part in HLAB27 associated SpA.

Various theories are proposed to explain the association of SpA with B27. Several of them involve some form of molecular mimicry. In these theories B27 functions as a T cell restriction element, as an antigen, or both as an antigen and a T cell restriction element: (1) B27 presents a bacterial derived peptide to B27 restricted CD8 positive CTL crossreacting with self peptides presented by B27. ${ }^{15}$ (2) B27 molecules would present a peptide derived from B27 itself with sequence similarity with bacteria. ${ }^{16}{ }^{17}$ (3) Peptides derived from the B27 molecule would be presented by MHC class II molecules to $\mathrm{CD} 4$ positive $\mathrm{T}$ cells that previously have been activated by bacterial antigens. ${ }^{18} 19$ (4) Antibodies induced by bacteria may crossreact with $\mathrm{B} 27$ molecules, thereby initiating an autoimmune response. ${ }^{20}$

In several studies data had been obtained that supported the idea that possible crossreactions between bacteria and the B27 molecule may be responsible for the induction of autoimmune reactions directed against the B27 molecule. Using polyclonal anti-sera raised in various animals, many groups studied a 
possible crossreactivity between several bacterial species (Klebsiella pneumoniae, Enterobacter aerogenes, Shigella sonnei, Yersinia enterocolitica, Chlamydia trachomatis) and HLA-B27. ${ }^{21-32}$ Possibly because of non-specific binding in the serological methods used, such crossreactions were not observed by all research groups. ${ }^{33-36}$ Using more specific monoclonal antibodies reactive with $\mathrm{B} 27$ or bacteria, it was demonstrated that crossreactivity between Yersinia enterocolitic, Shigella sonnei, Shigella flexneri, Salmonella typhimurium, Klebsiella pneumoniae and HLA-B27 may occur. Using polyclonal anti-Klebsiella sera some evidence was obtained that suggested the existence of a B27 associated crossreactive epitope that was specifically present on lymphocytes of AS patients, and only on B27 positive lymphocytes of healthy persons after incubation of these lymphocytes with a Klebsiella culture-filtrate derived factor. ${ }^{26} 31{ }^{32}{ }^{37}$ Later, serological recognition of B27 was shown to be influenced by oxidation of the free sulphydryl group of the cysteine at position 67 of the B27 molecule, something that can be achieved by interaction of B27 with homocysteine (a product produced by bacteria). Thus, certain factors were shown to be able to modify the serological properties of B27, which in people might lead to recognition of B27 as non-self. ${ }^{37-39}$ All these findings support the hypothesis that B27 associated SpA may be an AID, and that they may be caused by molecular mimicry between B27 and bacterial components. ${ }^{35}{ }^{40-42}$ It is, however, not at all clear whether the published data validate the classification of SpA as an AID attributable to molecular mimicry between HLA-B27 and bacteria.

The criteria for AID are not clearly defined. This has resulted in a tendency to consider some diseases of unknown origin as AID, even though the role of autoimmune phenomena in such diseases in humans are not clear at all. ${ }^{43}$ The term "autoimmunity" was first introduced at the beginning of this century by Ehrlich, who formulated the concept of "Horror autotoxicus" ${ }^{44}$ His concept is often misunderstood as meaning that autoantibodies may not be formed. The true meaning however is that autoantibodies may be formed and can be found, but that in healthy people mechanisms exist that somehow prevent their action and thus inhibit the development of AID. ${ }^{44}$

Sera from normal animals and humans of any age contain a wide variety of autoantibodies, including antibodies reactive with molecules involved in the immune system. Thus, the presence of autoantibodies in people with particular diseases, does not indicate that such antibodies play a part in the pathogenesis of these diseases, or that these diseases can be regarded as AID. The presence of autoantibodies only points to autoimmune reactivity and not necessarily to autoimmune disease. The induction of autoantibodies might be secondary to disease and have been induced for example by tissue damage because of nonautoimmune mechanisms. ${ }^{45-50}$

Nevertheless, autoantibodies in high titres can be useful diagnostic markers for certain diseases. Their presence, however, does not prove that autoimmune reactions really are the cause of diseases. Direct evidence as defined by Rose $^{51}$ is "the demonstration that a self reactive antibody is the immediate cause of injury or dysfunction". This has been demonstrated for the autoimmune forms of haemolytic anaemia, thrombocytopenia, leucopenia and for diseases where antibodies to receptors are involved, for example, Graves' hyperthyroidism and myasthenia gravis. According to Rose, ${ }^{51}$ indirect evidence for a pathogenetic role of autoantibodies requires the identification and isolation of the appropriate autoantigen. Subsequent immunisation of suitable animals with this antigen should reproduce the lesions of the disease. According to Rose, most of the so called autoimmune diseases are, however, only defined on the basis of circumstantial evidence, including the presence of other autoimmune disorders in the same person or in the family, associations with particular HLA haplotypes and a markedly skewed $\mathrm{T}$ cell receptor V-gene use. Feltkamp, ${ }^{43}{ }^{52}$ considering that all autoimmune diseases are characterised by autoimmune reactions, favours a more practical definition of an autoimmune disease: "An autoimmune disease is characterised by a significantly increased frequency of autoantibodies in significantly increased titres, compared to healthy local controls". Because for several human autoimmune diseases the preponderance of women is striking and sex hormones can modify immune responses, and as age and the hygienic quality of life of a population influence the chance for developing various autoimmune diseases, it is important to include local controls that are matched for sex and age in studies assessing AID. ${ }^{435354}$

Considering the above information the following definition can be used. "Autoimmune diseases are diseases in which immune reactivity directed against autologous antigens is significantly increased when compared to normal individuals, whilst this reactivity is the primary cause of tissue or cell destruction". Regarding $\mathrm{SpA}$, the aforementioned definitions mean that HLA-B27 associated SpA only can be designated as AID if the presence and nature of autoimmune reactions can be demonstrated. Thus, in SpA patients autoreactivity should be at least more often present in higher levels than in well defined controls, who should have to be matched for sex and for age. Assessment of autoantibodies and autoreactive $\mathrm{T}$ cells in cases and controls should have to be performed with the same techniques with the same sensitivity. As the MHC background has been shown to influence the susceptibility to certain autoimmune diseases, and as in B27 transgenic mice antibodies and $\mathrm{T}$ cell responses to B27 could not be induced by immunisation with B27 derived peptides compared with non-transgenic mice, controls should also have to be matched for HLA-B27. ${ }^{55}$ If sera or T cells are used to study whether they react both with HLA-B27 and bacteria, additional experiments have to be performed to confirm that crossreactive antibodies or $\mathrm{T}$ cells are present in the sera, to exclude the possibility that the crossreactivity was 
Table 1 Frequencies of presence of autoreactivity to antigens other than HLA-B27 in SpA patients and controls

\begin{tabular}{|c|c|c|c|c|}
\hline Immunereaction & Reference & Year & Humoral resp. $I g / A / G / M$ & Cellular assays \\
\hline Anti-69 kD protein & 62 & 1991 & Ig & \\
\hline Anti-anter.longit.ligament & 90 & 1983 & & Stim. \\
\hline Anti-articular cart(ilage) & 91 & 1976 & Ig & MI \\
\hline Anti-C1q & 92 & 1992 & $\mathrm{G}, \mathrm{A}$ & \\
\hline \multirow[t]{3}{*}{ Anti-cardiolipin } & 63 & 1987 & $\mathrm{G}+\mathrm{M}$ & \\
\hline & 64 & 1989 & Ig & \\
\hline & 57 & 1995 & $\mathrm{G}, \mathrm{M}, \mathrm{A}>16$ units & \\
\hline Anti-cart.link protein & 93 & 1988 & Ig & \\
\hline Anti-collagen n1;n2;n3; $\alpha$ & 94 & 1980 & & Stim. \\
\hline $\mathrm{d} 1$ & 95 & 1980 & & Stim. \\
\hline $\mathrm{n} 1 ; \mathrm{n} 2$ & 96 & 1980 & G & \\
\hline $\mathrm{n} 2$ & 97 & 1981 & $\mathrm{G}, \mathrm{M}$ & \\
\hline $\mathrm{d} 2 ; \mathrm{n} 2$ & 98 & 1984 & $\mathrm{G}$ & \\
\hline C2 peptides & 99 & 1994 & & CTL cloning \\
\hline $\mathrm{n} 2$ & 61 & 1997 & $\mathrm{G}, \mathrm{A}, \mathrm{M}$ & \\
\hline $\mathrm{n}$ & 60 & 1997 & & \\
\hline \multirow[t]{2}{*}{ Anti-DNA ss; ds } & 63 & 1987 & $\mathrm{G}, \mathrm{M}$ & \\
\hline & 69 & 1992 & $\operatorname{Ig}>1: 10$ & \\
\hline Anti-HSP60 & 56 & 1996 & G Mean Abs. & \\
\hline Anti-intervertebral disc & 90 & 1983 & & Stim. \\
\hline Anti-keratin & 100 & 1994 & A,G,M Mean Abs & \\
\hline ANCA & 101 & 1995 & $\mathrm{G}, \mathrm{A}$ & \\
\hline ANF Liver & 65 & 1967 & $\mathrm{Ig} \geqslant 1: 16$ & \\
\hline Liver & 66 & 1967 & Ig & \\
\hline Liver & 67 & 1967 & Ig $\geqslant 1: 16$ & \\
\hline Leucocytes & 58 & 1977 & Ig & \\
\hline Granulocytes; liver & 68 & 1979 & Ig $1: 40$ & \\
\hline \multirow[t]{2}{*}{ Leucocytes } & 59 & 1981 & $\operatorname{Ig} 1: 20$ & \\
\hline & 69 & 1992 & Ig $>1: 40$ & \\
\hline \multirow[t]{2}{*}{ Hep-2 } & 101 & 1995 & $\mathrm{G}$ & \\
\hline & 102 & 1993 & & \\
\hline \multirow[t]{3}{*}{$\mathrm{APF}$} & 103 & 1995 & Ig $1: 801: 100$ & \\
\hline & 104 & 1979 & $\operatorname{Ig} 1: 80$ & \\
\hline & 105 & 1990 & Ig $1: 80$ & \\
\hline Anti-sacroileac joint cart. & 90 & 1983 & & Stim. \\
\hline Anti-salivaryduct & 106 & 1967 & Ig & \\
\hline Anti-synovial membrane & 91 & 1976 & Ig & MI \\
\hline Anti-thyroglobulin & 107 & 1979 & Ig & \\
\hline Immunereaction & Reference & Osteoarthritis & Degenerative joint disease & Gout \\
\hline Anti-69 kD protein & 62 & & & \\
\hline Anti-anter.longit.ligament & 90 & & & \\
\hline Anti-articular cart(ilage) & 91 & & & \\
\hline Anti-C1q & 92 & & & \\
\hline \multirow[t]{3}{*}{ Anti-cardiolipin } & 63 & & & \\
\hline & 64 & & & \\
\hline & 57 & & & \\
\hline Anti-cart.link protein & 93 & $7 / 29$ & & \\
\hline Anti-collagen n1;n2;n3; $\alpha$ & 94 & & $0 ; 0 ; 0 ; 3 / 10$ & $0 ; 2 ; 1 ; 3 / 10$ \\
\hline d1 & 95 & & $3 / 15$ & \\
\hline $\mathrm{n} 1 ; \mathrm{n} 2$ & 96 & & & \\
\hline $\mathrm{n} 2$ & 97 & & & \\
\hline $\mathrm{d} 2 ; \mathrm{n} 2$ & 98 & & & \\
\hline C2 peptides & 99 & & & \\
\hline $\mathrm{n} 2$ & 61 & & & \\
\hline \multirow{3}{*}{ Anti-DNA ss; ds } & 60 & & & \\
\hline & 63 & & & \\
\hline & 69 & & & \\
\hline Anti-HSP60 & 56 & & & \\
\hline Anti-intervertabral disc & 90 & & & \\
\hline Anti-keratin & 100 & & & \\
\hline ANCA & 101 & & & \\
\hline ANA Liver & 65 & $0 / 8$ & & \\
\hline Liver & 66 & $0 / 15$ & & $0 / 13$ \\
\hline Liver & 67 & & & \\
\hline Leucocytes & 58 & & & \\
\hline Granulocytes/liver & 68 & & & \\
\hline \multirow[t]{2}{*}{ Leucocytes } & 59 & & & \\
\hline & 69 & & & \\
\hline Hep-2 & 101 & & & \\
\hline & 102 & & & \\
\hline APF & 103 & & & \\
\hline & 104 & & $2 / 32$ & \\
\hline & 105 & & & \\
\hline Anti-sacroileac joint cart. & 90 & & & \\
\hline Anti-salivaryduct & 106 & $0 / 43$ & & $0 / 6$ \\
\hline Anti-synovial membrane & 91 & & & \\
\hline Anti-thyroglobulin & 107 & & & $1 / 2 \mathrm{SF}$ \\
\hline
\end{tabular}

$\uparrow=$ Increased mean absorbance in ELISA. Bold type $\mathrm{e}^{\star}=$ significant $(\mathrm{p}<0.05)$ if compared with healthy controls. $+=$ Significantly increased frequency of autoimmune reactions among B27 associated SpA compared with controls (healthy or suffering from other rheumatic disorders). A = IgA, Abs = absorbance in ELISA assay, Arthr

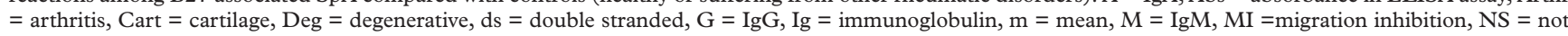
significant, resp = response, $\mathrm{SLE}=$ systemic lupus erythematosus, $\mathrm{SF}=$ synovial fluid, ss $=$ single stranded, Stim $=$ lymphocyte stimulation .

attributable to coexistent antibodies and $\mathrm{T}$ cells with different specificities for bacteria and B27.

In this study data from literature were collected to answer the question whether SpA can be designated as an AID, and whether crossreactivity between HLA-B27 and bacteria plays a part in the pathogenesis of B27 associated $\mathrm{SpA}$. 
Table 1 continued

\begin{tabular}{|c|c|c|c|c|}
\hline Ankylosing spondylitis & Reactive arthritis & Reiter syndrome & $S p A$ & $R A$ \\
\hline \multirow{2}{*}{\multicolumn{5}{|c|}{$0 / 8$}} \\
\hline Ig: 0/15 MI NS & & & & \\
\hline $\mathrm{G}: 3 / 40 \mathrm{~A}: 8 / 40$ & & & & G. $4 / 80 \mathrm{~A} \cdot 1 / 80$ \\
\hline $2 / 28$ & & & & $3 / 10$ \\
\hline $0 / 41$ & & & & $14 / 110$ \\
\hline \multicolumn{5}{|l|}{ G:24/84^ M:7/84 A:0/84 } \\
\hline 3/9 NS & & & & $9 / 38$ \\
\hline \multirow[t]{2}{*}{$2 ; 2 ; 2 ; 5 / 10$} & & & & $9 ; 10 ; 10 ; 16 / 20$ \\
\hline & & $1 / 9$ & & $16 / 38$ \\
\hline 6;6/20 Mean: 0,$87 ; 0,95^{\star}$ & & & & 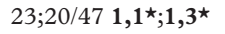 \\
\hline G: $5 / 18 \mathrm{M}: 1 / 18$ & & & & G:13/33 M: 18/33 \\
\hline $1 ; 1 / 4$ & & $2,0 / 2$ & & $37 ; 11 / 102$ \\
\hline 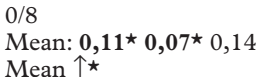 & $1 / 3$ & & & $\mathrm{~m}: \mathbf{0 , 2 5 ^ { \star }} 0,06 \mathbf{0 , 1 5 ^ { \star }}$ \\
\hline \multirow{2}{*}{$0 / 3$} & & & & $\mathrm{G}: 1 ; 0 / 10 \mathrm{M}: 2 ; 2 / 10$ \\
\hline & & $1 . \mathbf{6}^{\star} \mathrm{n}=9$ & & $0,87 \mathrm{n}=9$ \\
\hline \multicolumn{5}{|l|}{$0 / 8$} \\
\hline $9,15,13 \mathrm{n}=20 \mathrm{NS}$ & G:12/22 A:8/22 & $8,19,13 \mathrm{n}=11 \mathrm{NS}$ & & \\
\hline $\begin{array}{l}0 / 2 \\
0 / 27 \\
0 / 18(\mathrm{AS}+\mathrm{PsoA}) \\
75 / 125^{\star} \\
5 / 88 ; 6 / 36 \\
7 / 31^{\star} \\
0 / 3\end{array}$ & & $1 / 9$ & & $\begin{array}{l}31 / 110 \\
14 / 107 \\
59 / 184 \\
58 / 124^{\star}\end{array}$ \\
\hline & $0 / 22$ & \multicolumn{2}{|c|}{$0 / 3$} & \\
\hline \multicolumn{4}{|l|}{$7 / 84$} & \\
\hline $2 / 36$ & & & & $80 / 103$ \\
\hline $3 / 52$ & $2 / 26$ & & & $76 / 100$ \\
\hline \multicolumn{5}{|l|}{$0 / 8$} \\
\hline $0 / 1$ & & $2 / 9$ & & $34 / 129$ \\
\hline Ig: 0/15 MI>Contr. ${ }^{\star}$ & & & & $\mathrm{g}: 0 / 25 \mathrm{MI}>$ Contr. \\
\hline $1 / 1 \mathrm{SF}$ & & & & $5 / 41 \mathrm{SF}$ \\
\hline \multirow[t]{4}{*}{$S L E$} & Psoriatic arthritis & Normal controls & Sex/HLA matches & Conclusions \\
\hline & & $? / 38$ & No & \\
\hline & & $\mathrm{n}=8$ & No & \\
\hline & & $0 / 25$ & No & \\
\hline \multirow{2}{*}{ G:30/88 A:0/88 } & & $3 / 802 / 80$ & No & \\
\hline & & $0 / 10$ & No & \\
\hline \multirow[t]{2}{*}{$36 / 117$} & $2 / 19$ & $0 / 152$ & No & \\
\hline & & $\mathrm{G}: 2 / 40 \mathrm{M}: 3 / 40 \mathrm{~A}: 0 / 40$ & Sex + age & + \\
\hline $4 / 9$ & $7 / 13$ & $21 / 83$ & No & \\
\hline & & $0 ; 0 ; 0 ; 1 / 10$ & No & \\
\hline & & $3 / 17$ & No & \\
\hline & $0,0 / 14$ & $\mathrm{n}=40$ & No & \\
\hline & G: $0 / 14 \mathrm{M}: 1 / 14$ & $\mathrm{n}=15$ & No & \\
\hline $2 ; 0 / 8$ & & $2 ; 1 / 50$ & No & \\
\hline & & $0 / 4$ & No & \\
\hline & & m: $0,090,060,12$ & No & + \\
\hline & & $\mathrm{n}=30$ & No & + \\
\hline & & $\mathrm{G}: 0 ; 0 / 10 \mathrm{M}: 1 ; 1 / 10$ & No & \\
\hline & & & No & \\
\hline $1,0 \mathrm{n}=12$ & & $0,96 n=9$ & No & + \\
\hline & & $\mathrm{n}=8$ & No & \\
\hline & $24^{\star}, 11,12 \mathrm{n}=42$ & $9,13,16 n=58$ & No & \\
\hline & & & No & \\
\hline & $0 / 6$ & & No & \\
\hline & $0 / 7$ & & No & \\
\hline $55 / 55$ & 0/18 PsoA+AS & $0 / 66$ & No & \\
\hline & & $11 / 122$ & No & + \\
\hline & $7 / 52,1 / 32$ & & No & \\
\hline & & $0 / 31$ & Sex + age & + \\
\hline & & & No & \\
\hline & & & - & \\
\hline & & & No & \\
\hline & & & No & \\
\hline & & $4 / 111$ & No & \\
\hline & $5 / 34$ & $3 / 108$ & No & \\
\hline & & $\mathrm{n}=8$ & No & \\
\hline $1 / 4$ & $0 / 9$ & & No & \\
\hline & & $0 / 25$ & No & \\
\hline & & & No & \\
\hline
\end{tabular}

Source of data

The Medline database was searched with Ovid software for English language literature that appeared between 1966 and April 1998 using the following subject headings: spondylitis, ankylosing; arthritis, reactive; Reiter's syndrome. This resulted in 5082 references. This search was further limited to those with the 
following text words present in the title, abstract, or the subject headings: autoantigen or autoantigens; autoantibody or autoantibodies; autoreactive or autoimmune; serology or culture; antigen or antigens; antibody or antibodies; Salmonella or Yersinia or Chlamydia or Klebsiella or Shigella or Campylobacter; infection or infections; $\mathrm{T}$ cells or $\mathrm{T}$ lymphocytes; bacteria or bacterial. This resulted in 2516 references. All titles of these 2516 reports were used to exclude those reports that did not cover the subject of our study. In total, 1515 references were not appropriate. Usually, the above searched text words were only mentioned in other contexts. The remaining 1001 references were imported in a database using Reference Manager software. The abstracts of these 1001 articles were read to find those studies in which the presence and nature of autoimmune reactions in B27 associated SpA was studied. Again, the fall out usually consisted of reports in which the above searched text words were only presented in other contexts. Subsequently, reviews and case reports were excluded. Finally, only 45 articles reported on studies that were relevant for the question whether B27 associated SpA are AID, and 12 articles reported on studies that were relevant for the question whether $\mathrm{SpA}$ is caused by molecular mimicry between bacteria and B27.

\section{Results}

The results are presented in the following three paragraphs: Autoreactivity against antigens other than HLA-B27; Autoreactivity against HLA-B27; Crossreactivity between bacteria and HLA-B27.

\section{AUTOREACTIVITY AGAINST VARIOUS ANTIGENS} OTHER THAN HLA-B27

The 32 articles reporting on the measurement of autoimmune responses in B27 associated SpA, encompassed 30 studies on AS, six on RS and four on ReA. Of these 32 reports, 27 reported on autoantibody responses and only six on $\mathrm{T}$ cell autoreactivity. The antibodies studied, cover a wide range of different autoantigens including phospholipids, cartilage link protein, collagen like $\mathrm{C} 1 \mathrm{q}$, keratin, thyroglobulin, heat shock protein, perinuclear factor, nuclear antigens and neutrophil cytoplasmic antigens (ANCA).

In six studies, marked with "+" in the column "conclusion" in table 1 , the frequency or level of autoimmune reactions were significantly increased among B27 associated SpA patients compared with controls (healthy or suffering from other rheumatic disorders). ${ }^{56-61}$

Immunereaction against a $36 \mathrm{kDa}$ protein from Drosophila melanogaster was found to be increased in B27 positive and negative AS patients when compared with RA and healthy controls who were not matched for HLA or sex. ${ }^{62}$ When antibodies that reacted with the 36 $\mathrm{kDa}$ antigen were eluted from the $36 \mathrm{kDa}$ protein after incubation with pooled AS patient sera, it was found that these antibodies reacted with a $69 \mathrm{kDa}$ protein isolated from human lymphocytes or HeLa cells. Also pooled sera from AS patients reacted with this $69 \mathrm{kDa}$ protein. However, because in these studies pooled sera were used, it is not clear how many individual patients that recognise the $36 \mathrm{kDa}$ Drosophila protein also recognise the $69 \mathrm{kDa}$ human protein, and how many patient and control sera react with this $69 \mathrm{kDa}$ protein.

Levels of antibodies to HSP60, present in sera from RA, SLE, Reiter's patients and healthy controls, were reported to be slightly increased in sera from Reiter's patients in one study. ${ }^{56}$ The controls were not matched for HLA, sex or age.

One study reported a higher incidence of IgG anti-cardiolipin in AS patients compared with normal controls matched for age and sex, but not for HLA ${ }^{57}$ However, in two other studies in which no matches for HLA, sex and age were performed, the frequency of raised levels of anti-cardiolipin antibodies in sera from AS patients was not different compared with rheumatoid arthritis (RA) patients or healthy controls. ${ }^{6364}$

In only one of seven studies in which the presence of antibodies against collagen was analysed, AS patients had slightly increased levels of anti-collagen antibodies. ${ }^{6061}$ Controls were not matched for HLA, sex or age.

In three studies it was reported that no antinuclear antibodies (ANA) in AS patients and controls at a dilution of more than 1:16 were found, whereas $15 \%$ to $30 \%$ of RA patients were positive. ${ }^{65-67}$ At a dilution of 1:16 approximately $60 \%$ of 18 AS patients and $77 \%$ of 144 non-rheumatic disease controls were positive for ANAs, while $90 \%$ of 184 RA patients were positive. No HLA, sex, or age matches were performed. Vasey and Kinsella, ${ }^{58}$ testing for leucocyte reactive (LR) ANAs by measuring reactivity with granulocyte nuclei, found that $60 \%$ of 125 AS and $47 \%$ of 124 RA patients was positive. These percentages were significantly higher than for patients with inflammatory disorders ( $12 \%$ of 34 positive) and healthy controls ( $9 \%$ of 122 positive). Among 74 patients with miscellaneous disorders $40 \%$ was positive. Although no matches for HLA, sex, or age were used in this study, no correlation was found between the presence of $\mathrm{B} 27$ and LR-ANAs. The LR-ANAs in AS patients, although not granulocyte specific, were specific for leucocytes and did not react with other human or non-human substrates. This might explain the discrepancy with the negative results in the previous studies, ${ }^{65-67}$ in which liver tissue instead of granulocytes was used as substrate. LR-ANA positive sera from $50 \%$ of the RA patients and all SLE patients reacted also with adrenal and thyroid tissue as substrates. ${ }^{58}$ Rosenberg et $a l^{68}$ found that only $6 \%$ of 88 AS patients and $13 \%$ of 52 psoriatic arthritis (PsoA) patients had ANAs reactive with granulocytes, whereas all 25 psoriasis patients and 91 chest disease controls were negative. Measuring ANAs reactive with liver tissue they found that at serum dilutions of 1:40 17\% of $36 \mathrm{AS}$ and $3 \%$ of 32 PsoA patients were positive. These frequencies are rather low compared with other reports, ${ }^{65-67}$ except in the study of Vasey and Kinsella ${ }^{58}$ in which none of 
Table 2 Frequencies of the presence of anti-B27 antibodies in sera from SpA patients and controls

\begin{tabular}{|c|c|c|c|c|c|c|c|c|c|}
\hline \multirow{2}{*}{$\begin{array}{l}B \star 2705 \\
\text { residues: }\end{array}$} & \multirow[b]{2}{*}{ Reference } & \multicolumn{2}{|l|}{ AS patients } & \multicolumn{2}{|l|}{$R S$ patients } & \multicolumn{2}{|c|}{ Healthy controls } & \multirow[b]{2}{*}{ Titre } & \multirow[b]{2}{*}{ Match } \\
\hline & & $B 27^{+}$ & B27? & $B 27^{+}$ & $B 27$ ? & $B 27^{+}$ & $B 27 ?$ & & \\
\hline $69-84$ & Schwimmbeck et al $l^{20} 7071$ & $7 / 24 \star$ & & $18 / 34^{\star}$ & & $0 / 22$ & & $1: 10$ & $\mathrm{~B} 27$ \\
\hline $69-84$ & Tsuchiya $e t a l^{74}$ & $14 / 50$ & $14 / 60$ & $1 / 5$ & $1 / 8$ & $0 / 11$ & $1 / 25$ & $\begin{array}{l}1: 50 \\
\text { Norway }\end{array}$ & $\begin{array}{l}\text { B27 } \\
\text { Sex }\end{array}$ \\
\hline & & $2 / 26$ & & $0 / 6$ & $0 / 8$ & $0 / 6$ & $0 / 38$ & $\begin{array}{l}1: 50 \\
\text { N.Mexico }\end{array}$ & $100 \%$ male \\
\hline $68-75$ & Ewing $e t a l^{77}$ & $\begin{array}{l}\uparrow \mathbf{I g} \star \\
\mathrm{n}=50\end{array}$ & & & & $\mathrm{n}=22$ & & $1: 2000$ & $\mathrm{~B} 27$ \\
\hline $69-84$ & de Vries $e t a l^{78}$ & $\begin{array}{l}\uparrow \mathbf{I g}{ }^{\star} \\
\mathrm{n}=81\end{array}$ & & $\begin{array}{l}\uparrow \mathrm{Ig} \\
\mathrm{n}=38\end{array}$ & & $\mathrm{n}=32$ & $\mathrm{n}=49$ & $1: 50$ & $\begin{array}{l}\text { Sex } \\
79 \% \text { male }\end{array}$ \\
\hline $67-83$ & Tani et $a l^{2}$ & $\begin{array}{l}79 \% \text { male } \\
\uparrow \mathbf{A}^{\star}, \mathbf{G}^{\star}, \mathbf{M}^{\star} \\
\mathrm{n}=52 \\
90 \% \text { male }\end{array}$ & & $84 \%$ male & & $50 \%$ male & $\begin{array}{l}79 \% \text { male } \\
\mathrm{n}=50 \\
50 \% \text { male }\end{array}$ & $1: 50$ & - \\
\hline $67-83$ & Fielder $e t a l^{73}$ & $\begin{array}{l}\uparrow \mathbf{A}, \mathbf{G}^{\star}, \mathbf{M} \\
\mathrm{n}=97\end{array}$ & & & & & $\mathrm{n}=25$ & $1: 50$ & - \\
\hline
\end{tabular}

$\uparrow=$ Increased mean absorbance in ELISA. Bold type ${ }^{\star}=$ significant $(\mathrm{p}<0.05)$ if compared with healthy controls. $\mathrm{A}=\operatorname{IgA}, \mathrm{G}=\operatorname{IgG}, \mathrm{M}=\operatorname{IgM}, \mathrm{n}=$ number of subjects studied.

the sera from AS patients reacted with liver tissue. Rosenberg et $a l^{68}$ used fixed leucocytes as substrate, whereas Vasey and Kinsella ${ }^{58}$ used unfixed leucocytes. However, Rosenberg et $a l^{68}$ using unfixed leucocytes similar to those used by Vasey and Kinsella, were still not able to confirm the findings of Vasey and Kinsella. ${ }^{58}$ In these studies no HLA, sex or age matches had been performed. In a later study, Kinsella et al again found a higher incidence of LR-ANA in AS patients than in normal controls ( $45 \%$ of 31 AS patients, $7 \%$ of 31 controls at $1: 10$ dilution, and $23 \%$ of 31 AS, $0 \%$ of 31 controls at $1: 20$ dilution). ${ }^{59}$ In this study, patients and controls were matched for sex and age ( \pm 2 years), but HLA matches were not performed. All AS patients were B27 positive and almost all controls were B27 negative, but there was no concordance between LR-ANA and B27 positivity in North American natives. Wong et al ${ }^{69}$ testing only three patients with B27 positive AS and their family members for ANAs reactive with Hep-2 cells, found that at a dilution of $1: 40$, all persons had ANA reactivity within normal range.

\section{AUTOREACTIVITY AGAINST HLA-B27}

Schwimmbeck et $a l^{2070}$ used peptides from residues $69-84$ of HLA-B ${ }^{\star} 2705$, as substrate in an ELISA system to detect antibodies against B27. Eighteen of $34 \quad(53 \%) \quad$ B27 positive RS patients and 7 of $24(29 \%)$ B27 positive AS patients tested at a dilution of 1:10 were positive. None of the 22 B27 positive healthy controls were positive. Thus, patients were shown to have higher titres of antibodies against B27 than controls who were matched for HLA, but not for sex or age (table 2).

Tani $e t a l^{2}$ tested sera from Japanese patients at a dilution of 1:50 for antibodies to the 67-83 $B^{\star} 2705$ peptide with an ELISA, and found that active AS patients had significantly higher antibody levels against the $B^{\star} 2705$ peptide in all antibody subclasses, and that inactive AS patients had only raised IgG subclass antibody levels compared with healthy normals and RA patients. Antibody levels against a control peptide were not different in the different groups. All AS patients were B27 positive, but the controls were not matched for HLA, sex or age. Of the RA patients $90 \%$ were women, while $90 \%$ of the AS patients and $50 \%$ of the controls were men. Fielder et al ${ }^{73}$ using the same method and the same peptides, found that active AS patients had significantly higher IgG subclass antibody levels than RA patients and controls who were also not matched for HLA, sex or age. The levels of IgM and IgA subclasses were similar in patients and controls.

Tsuchiya et $a l^{74} 75$ used the same technique as Schwimmbeck with the 69-84 peptide from $B \star 2705$. Patients and controls from Tromso (Norway) were sex (only men were included) and age matched. The mean age of the patients was 38 years, ranging from 20 to 69 , and of the controls 40 years, ranging from 21 to 62 . Fourteen of $60(23 \%)$ AS patients of whom $83 \%$ were B27 positive, one of eight (13\%) RS patients of whom $63 \%$ were B27 positive, and one of 25 (4\%) normal controls of whom $44 \%$ were B27 positive, had antibodies against the B27 peptide 69-84. The difference of the positive ratio between $\mathrm{AS}$ and controls was only significant when no HLA matches were performed. However, when the same studies were performed on patients from New Mexico, no significant differences were found between patients and controls who were not matched for age. In a study using the lymphocyte migration inhibition test for patients as well as for controls, no significant differences were found between the migration inhibition (MI) induced by a B27 peptide and the MI induced by a control peptide. ${ }^{74}{ }^{75}$ When values of MI induced by the B27 peptide were compared with those induced by blank wells containing no peptides at all, it appeared that the proportion of normal controls responding to the B27 peptide was larger than that of patients, although the difference was not statistically significant $(p>0.10)$. The results obtained by ELISA used in this study were corrected for non-specific serum binding. Schwimmbeck et a ${ }^{2070} 71 \mathrm{had}$ not reported such correction. Women were excluded from the studies by Tsuchiya et al because they found increased titres against the B27 derived peptide were present in seven of $34(21 \%)$ B27 negative female controls and also in two of nine $(22 \%)$ B27 positive female controls who had previously been pregnant. Most of their female patients had been pregnant, and the titres in these patients were 
similar to the titres in the B27 positive or B27 negative female controls with previous pregnancies. The group of female patients without previous pregnancies was too small to study. Cavender et $a l^{76}$ found neither antibodies against B27 in any of six male AS or RS patients, nor in sex and age matched B27 negative controls. They used B27 positive lymphoblastoid cells as targets in a microlymphocytotoxicity assay.

Ewing $e t a l^{77}$ used a variety of synthetic peptides derived from HLA-B27 as substrates in ELISA systems. Analysing the specificity of a number of patient sera recognising peptides from $B^{\star} 2705$, they found two different reactive sites in the B27 peptides. Using octamers they observed that reactivity to the sequence 72-QTDREDLR-79 was absent, and that reactivity was mainly present to two peptides, 68-KAKAQTDR-75 and 76-REDLRTLL-83. At a dilution of 1:2000, sera from 50 B27 positive AS patients, and $22 \mathrm{~B} 27$ positive and 22 B27 negative healthy first degree relatives as controls were studied for antibodies to 68KAKAQTDR-75. The mean absorbance values in the ELISA of the sera from the patients were significantly higher than the mean absorbance of either groups of control sera. However, this difference was mainly caused by three of the 50 patient sera, which showed extremely high reactivity against B27. No significant differences between the mean absorbance values of the B27 positive and B27 negative controls were found. No sex or age matches were performed.

De Vries $e t a l^{78}$ used the same technique and peptide substrate $\left(69-84 \mathrm{~B}^{\star} 2705\right.$ peptide) as Schwimmbeck et $a .^{20}{ }^{70}$ They studied 81 B27 positive AS patients, 38 B27 positive RS patients, and $32 \mathrm{~B} 27$ positive and 49 non-typed healthy controls. Like Tsuchiya et $a l^{74}{ }^{75}$ they could not reproduce the results reported by Schwimmbeck et al, although their first findings confirmed the results of Schwimmbeck et al. Sera from AS patients bound the B27 peptide significantly better than the control serum samples. However, differences were only significant if the results from all patients were compared with those from non-HLA typed controls. The results from $\mathrm{B} 27$ positive patients and the B27 positive controls were not significantly different. Patients with RS showed a higher, although not significantly, binding than non-HLA typed controls. Binding of sera from 32 B27 positive healthy controls was relatively high, but this was caused by nine serum samples of which seven were obtained from women of whom no data of possible previous pregnancies were available. Control experiments carried out with uncoated wells or wells coated with an irrelevant peptide, showed that there was a highly significant correlation between binding to both the B27 peptide and an irrelevant peptide, and even to uncoated wells. Apparently the degree of a-specific binding was high. All groups were matched for sex ( $79 \%$ men), but not for age.

Hermann et $a l^{79}$ studied proliferation of peripheral blood lymphocytes (PBL) using 13 short synthetic peptides of B27. The only con- clusion that could be drawn from the results of this study was that B27 positive AS patients as well as B27 positive healthy controls recognise a peptide corresponding to residues 60-72 from $\mathrm{B}^{\star} 2705$. A peptide corresponding to residues 151-165 was recognised by almost all groups studied (B27 positive AS, B27 positive other SpA, B27 positive healthy, B27 negative healthy). These groups were only matched for B27 and not for sex or age.

All the above studies make use of short synthetic peptides. There are only very few reports studying the possible recognition of conformational epitopes on whole B27 molecules by antibodies or $\mathrm{T}$ cells.

Kellner et $a t^{80}$ used flow microfluorocytometry analysis to measure antibodies reacting with B27 positive cells transfected with the Mycobacterium tuberculosis HSP60 gene. Sera of 11 B27 positive AS patients, 13 B27 positive RS patients, six B27 positive healthy persons and 12 non-HLA typed healthy controls were studied. No sex or age matches were performed. They found that the mean fluorescence intensities for the RS patient sera and for the AS patient sera were significantly higher than for either control group sera. Experiments were done that indicated that this was mediated by serum antibodies that were recognising HLA-B27 complexed with peptides derived from the Mycobacterium tuberculosis HSP60.

Gao et $a l^{38}$ reported on cytotoxic $\mathrm{T}$ cell (CTL) recognition of homocysteine modificated B27 molecules. CTL in PBL cultures of two of three B27 positive AS patients, one of one $\mathrm{B} 27$ positive ReA patient and none of two healthy controls of which one was B27 positive, specifically recognised homocysteine modificated B27 molecules on autologous B cell lines. No sex or age matches were performed. HLAA68 restricted homocysteine specific CTL (Hom-CTL) from a B27 negative patient also recognised Salmonella infected target cells, suggesting that also Salmonella infection can lead to the modification of HLA antigens that is recognised by Hom-CTL.

Hermann et $a l^{81}$ found in synovial fluid from four (one B27 negative, three B27 positive) of six SpA patients (four ReA, two AS) a significant frequency of autoreactive CTL. Also B27 restricted autoreactive CTL clones specific for an as yet unidentified peptide were isolated. No studies were done on synovial fluid from controls.

CROSSREACTIVITY BETWEEN BACTERIA AND HLA-B27

After the sequence of the B27 molecule had been unravelled, more precise data about possible crossreactive epitopes on B27 and bacteria could be obtained than from experiments with antisera raised in animals. Using DNA hybridisation techniques, some sequence homologies between Klebsiella pneumoniae and Klebsiella otica and B27 were thought to be present, especially between these bacteria and the $66-74$ region located within the $B^{\star} 2705$ hypervariable region..$^{82} 83$

Schwimmbeck et a ${ }^{207071}$ used computer searches to identify sequence homologies 
Table 3 Amino acid sequences of HLA-B27 compared with the sequences of bacterial proteins

\begin{tabular}{|c|c|c|c|c|c|c|c|c|c|c|c|c|c|c|c|c|c|c|c|c|c|c|}
\hline Antigens & Residues & & no ac & $(r$ & dues & in bo & are & omo & gous & vith & $\star 27$ & & & & & & & & & & & \\
\hline $\mathrm{B}^{\star} 2705 \mathrm{~B}^{\star} 2703 \mathrm{~B}^{\star} 2707 \mathrm{~B}^{\star} 2709$ & $67-84$ & & & & $\mathbf{C}$ & $\mathbf{K}$ & $\mathbf{A}$ & $\mathbf{K}$ & $\mathbf{A}$ & $\mathbf{Q}$ & $\mathbf{T}$ & $\mathbf{D}$ & $\mathbf{R}$ & $\mathbf{E}$ & $\mathbf{D}$ & $\mathbf{L}$ & $\mathbf{R}$ & $\mathbf{T}$ & $\mathbf{L}$ & $\mathbf{L}$ & $\mathbf{R}$ & $\mathbf{Y}$ \\
\hline$B \star 2701$ & - & & & & - & - & - & - & - & - & - & $\mathrm{Y}$ & - & - & $\mathrm{N}$ & - & - & - & A & - & - & - \\
\hline$B \star 2702$ & - & & & & - & - & - & - & - & - & - & - & - & - & $\mathrm{N}$ & - & - & I & A & - & - & - \\
\hline $\mathrm{B}^{\star} 2704$ & - & & & & - & - & - & - & - & - & - & - & - & - & $\mathrm{S}$ & - & - & - & - & - & - & - \\
\hline$B \star 2706$ & - & & & & - & - & - & - & - & - & - & - & - & - & $\mathrm{S}$ & - & - & - & - & - & - & - \\
\hline $\mathrm{B}^{\star} 2708$ & - & & & & - & - & - & - & - & - & - & - & - & - & $\mathrm{S}$ & - & - & $\mathrm{N}$ & - & $\mathrm{R}$ & G & - \\
\hline Klebsiella Nitrogenase & $183-200$ & & & & I & C & $\mathrm{N}$ & $S$ & $\mathrm{R}$ & $\mathbf{Q}$ & $\mathbf{T}$ & D & $\mathbf{R}$ & $\mathbf{E}$ & D & $\mathrm{E}$ & $\mathrm{L}$ & I & I & $\mathrm{A}$ & $\mathrm{L}$ & \\
\hline Klebsiella PulD & $590-605$ & & & & & $\mathrm{R}$ & $\mathrm{P}$ & $\mathrm{T}$ & $\mathrm{V}$ & I & $\mathrm{R}$ & D & $\mathbf{R}$ & $\mathrm{D}$ & $\mathrm{E}$ & $\mathrm{Y}$ & $\mathbf{R}$ & $\mathrm{Q}$ & A & $\mathrm{S}$ & $\mathrm{S}$ & \\
\hline Shigella pHS-2 & & & & & G & $\mathrm{T}$ & $\mathrm{V}$ & $\mathrm{C}$ & A & $\mathbf{Q}$ & $\mathbf{T}$ & D & $\mathbf{R}$ & $\mathrm{H}$ & $\mathrm{S}$ & $\mathbf{L}$ & $S$ & $\mathrm{C}$ & I & A & $\mathrm{M}$ & Q \\
\hline Yersinia (O:3) Yop 1 & $171-188$ & & & A & I & G & $\mathrm{D}$ & $\mathrm{R}$ & $\mathrm{S}$ & $\mathrm{K}$ & $\mathbf{T}$ & $\mathbf{D}$ & $\mathbf{R}$ & $\mathbf{E}$ & $\mathrm{N}$ & $\mathrm{S}$ & $\mathrm{V}$ & $\mathrm{S}$ & I & G & $\mathrm{C}$ & \\
\hline Salmonella $\mathrm{OMP}-\mathrm{H}$ & $50-68$ & Q & $\mathrm{R}$ & $\mathrm{L}$ & $\mathrm{Q}$ & $S$ & $M$ & $\mathbf{K}$ & $\mathbf{A}$ & G & $S$ & D & $\mathbf{R}$ & $\mathrm{T}$ & $\mathrm{K}$ & $\mathbf{L}$ & $\mathrm{E}$ & $\mathrm{K}$ & $\mathrm{D}$ & $\mathrm{V}$ & & \\
\hline
\end{tabular}

between the $B^{\star} 2705$ sequence and known sequences from bacteria. They found a homology of six consecutive amino acids (QTDRED) shared by $\mathrm{B}^{\star} 2705$ residues $72-77$ located in the hypervariable region of the B27 molecule and Klebsiella pneumonia nitrogenase 188-193. This is a hydrophilic sequence, and is thus predicted to be located at the outside of the protein possibly accessible to antibodies. Later, sequence similarities between $\mathrm{B}^{\star} 2705$ and proteins of other bacteria than Klebsiella were also identified. Table 3 shows the sequence similarities between some bacterial proteins and the various B27 subtypes.

Schwimmbeck et al ${ }^{20} 70$ raised antibodies in rabbits reacting both with peptides from $\mathrm{B}^{\star} 2705$ and peptides from Klebsiella pneumoniae nitrogenase. If the rabbits were immunised with B27 or Klebsiella nitrogenase synthetic peptides containing the homologous sequence, it was shown that affinity purified antibodies raised against either peptide also reacted with the other peptide. Although Tsuchiya et $a l^{84}$ found the same results, De Vries et $a l^{78}$ were not able to reproduce these findings.

Schwimmbeck et $a l^{2070}$ also tested sera from AS and RS patients for reactivity against the peptide derived from Klebsiella nitrogenase 184-CNSRQTDREDEL-196 containing the homologous 72-QTDRED-77 B27 sequence.
As shown in table 4, they found that the frequency of antibodies against this peptide in sera from patients was higher than in sera from controls. This is in agreement with their finding that the frequency of antibodies against a B27 derived peptide containing residues 69-84 is increased..$^{2070} 71$ No cross inhibition studies were performed to study whether these antibodies were indeed crossreactive antibodies, and no age or sex matches were performed.

Tsuchiya et $a l^{4}$ found that the reactivity to Klebsiella nitrogenase peptide containing residues 184-196, in sera from B27 positive male patients and B27 positive male controls, either from Norway or New Mexico was not different. The mean age of Norwegian patients and controls was 38 years ranging from 20 to 69 , and 39 years ranging from 21 to 62, respectively. The mean age of the New Mexican patients and controls was 43 years ranging from 16 to 76 , and 40 years ranging from 25 to 66 respectively. Although sera from some patients were reactive with the Klebsiella peptide, there was no positive correlation between a positive reaction with the Klebsiella nitrogenase peptide and a positive reaction with the $\mathrm{B} 27$ peptide $69-84$. Cross inhibition studies were negative.

A very elegant study was carried out by Ewing et $a l^{77}$ Using overlapping peptides of eight residues from the $\mathrm{B}^{\star} 2705$ molecule, they

Table 4 Frequencies of presence of anti-bacterial antibodies in sera from SpA patients and controls

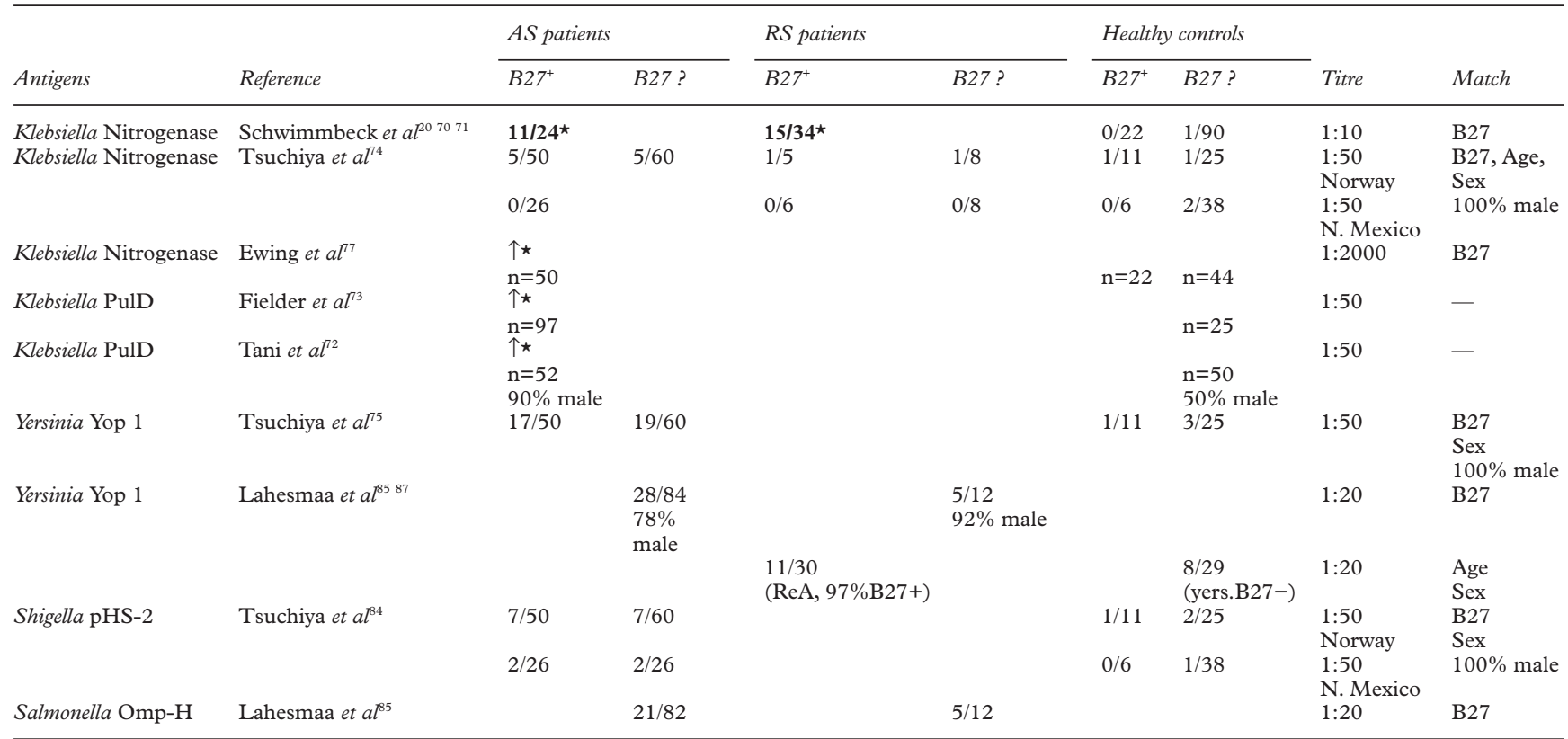

$\uparrow=$ Increased mean absorbance in ELISA. Bold type ${ }^{\star}=$ significant $(\mathrm{p}<0.05)$ if compared with healthy controls. yers $=$ uncomplicated yersiniosis. Other abbreviations as in table 2 . 
showed that in fact the antibody response against the part of $\mathrm{B}^{\star} 2705$ containing the Klebsiella homologous sequence was not directed to the complete homologous 72QTDRED-77 sequence, but rather to flanking regions that included only a few of the homologous residues - that is, 68KAKAQTDR-75 and 76-REDLRTLL-83 of HLA-B27. Interestingly, they found that sera reacting with peptides derived from Klebsiella nitrogenase also did not recognise octapeptides containing the complete homologous sequence, but an epitope containing QTDR and residues to the left of this sequence that is not homologous to $\mathrm{B}^{\star} 2705$-that is, 185 NSRQTDR-191. Fifty B27 positive AS patient sera and sera from 22 B27 positive and 22 B27 negative first degree relatives were tested for reactivity to the 185-NSRQTDR-191 Klebsiella peptide with ELISA assays. In patient sera the binding as measured by the mean absorbance value in the ELISA was significantly $(p<0.002)$ higher than in sera from the B27 negative control group, and also (but less significant, $\mathrm{p}<0.02$ ) than that in sera from the B27 positive control group. No age matches were performed. The overall conclusion by Ewing et al from their experiments was that sera from AS patients contained antibodies that reacted with overlapping epitopes of 5 to 8 amino acids within the sequence 183ICNSRQTDR-191 on the Klebsiella nitrogenase molecule. Sera from AS patients showed a positive correlation between binding to the B27 peptide 68-KAKAQTDR-75 and binding to the Klebsiella peptide 185-NSRQTDR-191. However, no cross inhibition studies, and studies with monoclonal or affinity purified antibodies were carried out, to show that antibodies were indeed crossreactive. Although QTDR seems to be an important sequence for antibody binding, the 4 amino acid peptide QTDR alone or QTDRED showed little reactivity with AS patient sera.

Tsuchiya $e t a l^{84}$ found that only three of 15 affinity purified anti-B27 peptide antibodies from AS patients showed a weak crossreactivity with the Klebsiella nitrogenase peptide 184CNSRQTDRED-197. The experiments in which different peptides were used, showed that the ELISA used was specific for peptides containing certain amino acid residues. Lahesmaa et al, however, found that sera reacting with CNSRQTDREDELI also reacted with peptide CNSRRQDDTEELI containing the same amino acids but in which the crossreactive sequence was scrambled. ${ }^{85}$

A computer search by Fielder et al revealed another sequence homology between a bacterial protein and HLA-B27. ${ }^{73}$ The PulD secretion protein of the starch inducible starch debranching enzyme pullulanase contains a sequence DRDE, which shows some similarity with DRED of $\mathrm{B}^{\star} 2705$. Peptides 67CKAKAQTDREDLRTLL-82 from $\mathrm{B}^{\star} 2705$ and 590-RPTVIRDRDEYRQASS-605 from PulD were used as substrates to study the reactivity of patient and control sera. They found significantly increased antibody levels in sera from AS patients compared with controls or
RA patients. No experiments were done to confirm the presence of crossreactive antibodies in positive sera. Patients and controls were not matched for HLA, sex or age. Control peptides from the scrambled PulD sequence were used to confirm sequence specificity of the tests.

Tani et $a l^{2}$ found significantly increased titres of IgG and IgA against the PulD peptide in sera from active AS patients compared with sera from controls. No HLA, sex or age matches were performed, and controls were only $50 \%$ men compared with $90 \%$ men in the AS group. No differences were found in antibody levels against a control peptide, consisting of a scrambled sequence of the pulD peptide, between the different groups. However, the absorbance values obtained with the control peptides were much higher $( \pm 0.7)$ for all groups studied than those obtained with Klebsiella peptides and sera with negative $( \pm 0.15)$ and positive $( \pm 0.45)$ reactions.

Sequence similarities between $B \star 2705$ and proteins of other Gram negative bacteria than Klebsiella were also studied. ${ }^{75-86}$ It was found that Shigella flexneri strains that are isolated from ReA patients carry a plasmid (pHS-2) ${ }^{86}$ DNA sequence analyses of this plasmid revealed that it contains an open reading frame (ORF) encoding a 22 amino acid peptide with sequence homology to B27, again involving the sequence QTDR - that is, GTVCAQTDRHSLSCIAMQ. Affinity purified rabbit antibodies against $\mathrm{B}^{\star} 2705$ showed a strong reactivity with the pHS-2 peptide. Of 15 affinity purified anti-B ${ }^{\star} 2705$ peptide antibodies from B27 positive patients only three recognised the Klebsiella nitrogenase 184-196 peptide, while 12 showed strong crossreactivity with the pHS-2 peptide. Affinity purified anti-B ${ }^{\star} 2705$ peptide antibodies from these patients reacted with whole Shigella bacteria that contained the pHS-2 plasmid, but also with plasmid negative Shigella bacteria. This finding suggests that these antibodies were not directed to the peptide encoded by the pHS-2 plasmid, and that the tests used were not specific for antibodies against sequences encoded by this plasmid. When large numbers of AS and RS patient sera from Norway or New Mexico were studied, only a relatively low level of reactivity to the pHS-2 peptide was demonstrated. ${ }^{84} \mathrm{~A}$ higher proportion of AS patients compared with controls recognised the pHS-2 peptide and patients had increased titres against this peptide, although the differences were not significant.

The sera from the same Norwegian patients were used to study reactivity to a peptide from Yop1 of Yersinia enterocolitica, as Tsuchiya had identified sequence homology between $B^{\star} 2705$ and the plasmid encoded Yop 1 from Yersinia enterocolitica $\mathrm{O}: 3$ and Yersinia pseudotuberculosis, in contrast with Yop1 of the non-ReA associated Yersinia enterocolitica O:8. ${ }^{75}$ The 171AIGDRSKTDRENSVSIGC-188 peptide used in the ELISA contained the homologous sequence. A larger but not significant higher proportion of Norwegian AS patients had increased anti-Yop1 antibody levels than 
Norwegian controls, especially IgA antibodies. However, anti-Yop1 antibody levels were not correlated with anti-B27 peptide antibody levels, although in one patient cross inhibition of the anti-Yop1 peptide antibodies with the B27 peptide was found. The mean age of the patients was 38 years, ranging from 20 to 69 . Controls used were matched and had a mean age of 40 years, ranging from 21 to 62 .

Another sequence homology exists between $\mathrm{B}^{\star} 2705$ and OMP-H of Salmonella typhimurium, again within the hypervariable region of B27. Lahesmaa et $a l^{p 5}$ tested for antibodies against the Yersinia enterocolitica O:3 Yop1, as well as for antibodies against the peptide from OMP-H containing the homologous sequence-that is, 50QRLQSMKAGSDRTKLEKDV-68, in sera from AS, RS and ReA patients and healthy controls without performing HLA, sex or age matching. Thirty three per cent of AS patients and $42 \%$ of RS patients had antibodies against the Yop 1 peptide, and $25 \%$ of AS patients and $40 \%$ of RS patients had antibodies against OMP-H. No data about healthy controls were included. The antibodies against Yop 1 were not directed against a part of the peptides with B27 homology, but to a flanking region left from this sequence. In this study it was also found that anti-Klebsiella pneumoniae nitrogenase antibodies were not directed against the $B \star 2705$ homologous sequence, but against a flanking region.

In 1992 a study from Lahesmaa ${ }^{87}$ was published in which 30 yersiniosis patients with ReA (one B27 negative, 30\% female), 29 uncomplicated yersiniosis patients (all B27 negative, $34 \%$ female) and 79 controls with various rheumatic diseases other than $\mathrm{SpA}$ or with infections by bacteria other than Yersinia. They tested sera of these subjects for antibody reactivity against the $171-188$ Yop 1 peptide. Thirty two per cent of the yersiniosis patients had antibodies against this peptide compared with only $4 \%$ of controls (two had RA, one had a Klebsiella infection). The antibodies were mostly IgA, and only two patients (without arthritis) had IgG antibodies reactive with the Yop 1 peptide. No difference in frequencies was found between the yersiniosis patients with arthritis and those without arthritis. Experiments were also performed to determine more precisely the sequence specificity of the antibody reactivity. These showed that the antibodies were not directed against the tetrapeptide shared by Yop 1 and B27, but against a left flanking sequence of Yop 1. While proliferation against whole Yersinia lysates was present, no lymphocyte proliferation against the Yop 1 peptide was found when 15 yersiniosis patients (eight with $\operatorname{ReA}$ ) and 16 healthy controls (50\% B27 positive) were tested. None of the yersiniosis patients had IgG or IgA against the 184-197 Klebsiella nitrogenase peptide.

\section{Conclusions}

From the data available in the literature it can be concluded that there are no consistent results confirming the presence of increased autoreactivity in $\mathrm{SpA}$ patients compared with controls. When reviewing the literature on this subject, some problems are encountered.

The results reported by the different groups are obtained by various methods, different dilutions of sera are tested, and different antigen preparations have been used. In addition, another problem is the specificity of the ELISA assays used. Tsuchiya ${ }^{75}$ and Lahesmaa ${ }^{85}$ showed that experiments with appropriate control peptides should be carried out to confirm the sequence specificity of the ELISA assays used. De Vries et $a l^{78}$ clearly showed that a correction for non-specific binding of sera used in the ELISA assays is required. In none of the studies with positive findings, using sex and HLA matched controls, such corrections were done. The main problem, however, in determining the presence of autoreactivity in B27 associated $\mathrm{SpA}$ is that only in a few studies HLA, sex and age matched controls were included, as shown in table 1 , table 2 , and table 4 .

The first studies showing an increased reactivity against B27 in the sera of AS and RS patients were done by Schwimmbeck et $a l^{20}{ }^{7071}$ However, their findings could only be confirmed in those studies lacking both HLA and sex matched controls. ${ }^{72} 7377$ Studies from groups using HLA and sex matches were not able to reproduce the results. Tsuchiya $\mathrm{et} \mathrm{al}^{74}{ }^{75}$ who found very high anti-B27 activity in some healthy B27 negative or even B27 positive women with previous pregnancies, illustrated the importance of using sex matches. ${ }^{74} 75$

The above mentioned problems also apply for the studies determining the presence of antibodies crossreacting with B27 and bacterial proteins. It is clear that sequence similarities between HLA-B27 and some bacterial proteins exist, and that at least in rabbits antibodies reacting with both bacterial proteins and B27 can be raised. The relevance of this finding for the pathogenetic mechanisms in B27 associated $\mathrm{SpA}$ is not evident, and inconsistent data about the presence of these antibodies in patients are obtained. When the frequencies of the presence of antibodies against bacterial proteins and B27 in sera from AS and RS patients were compared with those in sera from healthy controls, the latter were almost never properly matched for age, while only three studies performed sex and HLA matches. Most studies did not perform any experiments to confirm the crossreactivity of antibodies. Tsuchiya $^{75}$ and Lahesmaa ${ }^{85}$ clearly showed that experiments with appropriate control peptides should be carried out to determine the specificity of affinity purified antibodies.

Of the studies on crossreactive antibodies, in which controls were matched both for HLAB27 and sex, one study found increased reactivity to Yersinia Yop 1 in patients. ${ }^{75}$ However, although in one patient cross inhibition of the anti-Yop 1 peptide antibodies with the B27 peptide was found, there was no correlation with anti-B27 peptide antibody levels. Another study produced negative results with Klebsiella nitrogenase. ${ }^{74}$ A positive correlation was found between recognition of B27 and 
pHS-2 peptides, and crossreaction of affinity purified anti-B27 antibodies with pHS-2 was observed in 13 of 15 patients who recognised B27. However, a statistically non-significant higher proportion of AS patients recognised the Shigella pHS-2 peptide. ${ }^{84}$

Some results suggest that in people with an anti-B27 response, the antibodies are not directed to parts of the B27 molecule showing sequence similarities with bacterial proteins, but rather to flanking regions. ${ }^{77} 85$ This is in agreement with findings that mice transgenic for HLA-B ${ }^{\star} 2705$ and human $\beta_{2}$-microglobulin are tolerant to the $\mathrm{B} 27$ and bacterial crossreactive epitopes, ${ }^{55}$ and that peptides from regions that are non-homologous to self proteins are more readily recognised by the immune system than peptides from parts that are more homologous to self. ${ }^{88}$

The sequence similarities between B27 and the bacterial proteins nitrogenase, pullulanase, Yop 1, pHS-2, and OMP-H, are located in a region of $\mathrm{B} 27$ where different $\mathrm{B} 27$ subtypes differ in one or more amino acids. The crossreactive sequences of the B27 molecule are completely identical in B27 subtypes associated with disease $\left(B^{\star} 2705\right.$ and $\left.B \star 2707\right)$ and a subtype that is probably not associated with disease $\left(\mathrm{B}^{\star} 2709\right)$. The sequence similarities with bacterial proteins in $B^{\star} 2704$ (which is associated with disease), and $\mathrm{B}^{\star} 2706$ (which is not associated with disease) are also identical, but differ both from $B^{\star} 2705$ by a $D$ to $S$ substitution at residue 77 . Schwimmbeck et $a l^{11}$ reported a strong influence of the sequence differences as found in parts of the various B27 subtypes containing the reported sequence similarities with bacterial proteins on anti-B27 antibody binding. They found that a single amino acid change of $\mathrm{D}$ to $\mathrm{N}$ (as found at residue 77 in $B^{\star} 2701$ and $B^{\star} 2702$ ) significantly reduced recognition by affinity purified antibodies raised against a $B^{\star} 2705$ peptide, while a change of $\mathrm{D}$ to $\mathrm{S}$ (as found at residue 77 in $B^{\star} 2704, B^{\star} 2706$ and $B^{\star} 2708$ ) completely abolishes this reactivity. This suggests that antibodies against these parts of the B27 molecule, containing the reported sequence similarities with the above mentioned bacterial proteins, are not likely to be involved in B27 associated disease.

HLA-B27 is not the only HLA molecule sharing sequence similarities with bacterial proteins ${ }^{16}$ After the first studies had been published in which the role of molecular mimicry in B27 associated $\mathrm{SpA}$ was investigated, it has been suggested that the small chance that a sequence of 6 amino acids occurs in two different proteins, being only 1:64000 $000\left(1: 20^{6}\right)$, supported the idea that molecular mimicry plays a part in the onset of B27 associated diseases. ${ }^{20}{ }^{70}$ However, if a protein of $x$ amino acids is screened for a perfect 6 amino acid match in a database of $n$ amino acids the expected number of perfect matches is $0.05^{6} \times$ $n \times x$. Searching the SWISS-PROT database of 1996 that contained $1.5 \times 10^{7}$ residues for a perfect six amino acid match with a 360 amino acid protein like $\mathrm{B} 27$, one would expect $0.05^{6} \times 1.5 \times 10^{7} \times 360=84$ matches. ${ }^{89}$ Therefore, it is actually very possible to find 5,6 and 7 amino acid matches between unrelated proteins, ${ }^{88}$ and indeed this is found for HLA-B27 as well as for other HLA-B alleles. ${ }^{16}$

Only very few experiments have been carried out to determine $T$ cell reactivity against B27 in patients and controls. Interesting results have been obtained that suggest that the three dimensional structure of B27 can be modified by peptides or by homocysteine, thereby creating new conformational epitopes that are recognised by antibodies as well as $T$ cells of some SpA patients. ${ }^{38}{ }^{80}$ However, too few data are yet available about the presence of B27 specific, MHC class I or MHC class II restricted, $\mathrm{T}$ cell responses in patients and controls.

From this review it is concluded that there is no evidence that B27 associated diseases are autoimmune diseases as a consequence of autoimmune reactions. Although the $\mathrm{B} 27 \mathrm{~mol}-$ ecule shares some immunological determinants with bacterial constituents, there is no proof that these determinants are important for the pathogenesis of $\mathrm{B} 27$ associated $\mathrm{SpA}$. Although some patients and healthy people produce antibodies to $\mathrm{B} 27$ and crossreactive antibodies to both $\mathrm{B} 27$ and bacterial proteins, there is no evidence that the frequency of increased titres of such antibodies in sera from patients is significantly higher than in sera from matched controls.

Funding: this study is published with support of the Edmond and Marianne Blauw Fund for Ophthalmology.

I would like to thank (in alphabetical order) the following persons for their contributions and for critically reading the manuscript: Dr L van Alphen, Laboratory of Vaccine Development and Immune Mechanisms, National Institute of Public ment and Immune Health and the Environment, Bilthoven, the Netherlands; Pro dr J Dankert, Department of Medical Microbiology, Academic Medical Center, University of Amsterdam,the Netherlands;
Prof dr T E W Feltkamp, Arthron, Amsterdam, the NetherProf de

1 Dougados M, van der Linden S, Juhlin R, Huitfeldt B, Amor B, Calin A, et al. The European spondyloarthropathy study group preliminary criteria for the classification of spondygroup preliminary criteria for the classification of

2 Aho K, Ahvonen P, Lassus A, Sievers K, Tilikainen A. HL-A antigen 27 and reactive arthritis. Lancet 1973;ii: 157.

3 Brewerton DA, Hart FD, Nicholls A, Caffrey M, James DC, Sturrock RD. Ankylosing spondylitis and HL-A 27. Lance 1973;i:904-7.

4 Schlosstein L, Terasaki PI, Bluestone R, Pearson CM. High association of an HL-A antigen, W27, with ankylosing spondylitis. N Engl J Med 1973;288:704-6.

5 Brewerton DA, Caffrey MFP, Nicholls A, Walters D, Oates JK, James DC. Reiter's disease and HL-A 27. Lancet 1973; ii: $996-8$

6 Aho K, Ahvonen P, Lassus A, Sievers K, Tililikainen A. HLA-B27 in reactive arthritis. A study of Yersinia arthritis and Reiter's disease. Arthritis Rheum 1974;17:521-6.

7 Sieper J, Braun J. Pathogenesis of spondyloarthropathies. Areper J, Braun J. Pathogenesis of

8 Benjamin R, Parham P. Guilt by association. Immunol Today 1990;11:137-42.

9 Brown M, Wordsworth P. Predisposing factors to spondyloarthropathies. Curr Opin Rheumatol 1997;9:308-14

10 Ebringer A. Ankylosing spondylitis is caused by Klebsiella. Evidence from immunogenetic, microbiologic, and serologic studies. Rheum Dis Clin North Am 1992;18:105-21.

11 Fujinami RS. Molecular mimicry. In: Peter JB, Shoenfeld Y. eds. Autoantibodies. Amsterdam: Elsevier Science, 1996 507-12.

12 Damian RT. Molecular mimicry: antigen sharing by parasite and host and its consequences. American Naturalist 1964; 98:129-49.

13 Fujinami RS, Oldstone MB, Wroblewska Z, Frankel ME, Koprowski H. Molecular mimicry in virus infection: crossreaction of measles virus phosphoprotein or of herpes simreaction of measles virus phosphoprotein or of herpes simplex virus protein with human int

14 Fujinami RS, Oldstone MB. Amino acid homology between the encephalitogenic site of myelin basic protein and virus: mechanism for autoimmunity. Science 1985;230:1043-5. 
15 Blaauw I, van der Linden S, Nohlmans L. An increased prevalence of anti-Borrelia burgdorferi antibodies in ankylosing spondylitis: fact or artefact? Scand J Rheumato 1990;87(suppl 2):148.

16 Scofield RH, Warren WL, Koelsch G, Harley JB. A hypothesis for the HLA-B27 immune dysregulation in spondyloarthropathy: contributions from enteric organisms, B27 structure, peptides bound by B27, and

17 Scofield RH, Kurien B, Gross T, Warren WL, Harley JB. HLA-B27 binding of peptide from its own sequence and similar peptides from bacteria: implications for spondyloarthropathy. Lancet 1995;345:1542-4.

18 Davenport MP. The promiscuous B27 hypothesis. Lancet 1995;346:500-1

19 Parham P. Presentation of HLA class I-derived peptides: potential involvement in allorecognition and HLA-B27associated arthritis. Immunol Rev 1996;154:137-54.

20 Schwimmbeck PL, Oldstone MB. Autoimmune pathogenesis for ankylosing spondylitis (AS) and Reiter's syndrome (RS): autoantibodies against an epitope shared by HLA B27 and Klebsiella pneumoniae nitrogenase in sera of HLA B27 patients with AS and RS. Trans Assoc Am Phys 1987;100:28-39.

21 Ebringer A. The cross-tolerance hypothesis, HLA-B27 and ankylosing spondylitis. Br J Rheumatol 1983;22:53-66.

22 Kuberski TT, Morse HG, Rate RG, Bonnel MD. Increased recovery of Klebsiella from the gastrointestinal tract of Reiter's syndrome and ankylosing spondylitis patients. Br J Rheumatol 1983;22:85-90.

23 Welsh J, Avakian H, Cowling P, Ebringer A, Wooley P, Panayi G, et al. Ankylosing spondylitis, HLA-B27 and Klebsiella. I. Cross- reactivity studies with rabbit antisera. Br J Exp Pathol 1980;61:85-91.

24 Avakian H, Welsh J, Ebringer A, Entwistle CC. Ankylosing spondylitis, HLA-B27 and Klebsiella. II. Cross-reactivity studies with human tissue typing sera. Br J Exp Patho 1980;61:92-6.

25 Trull AK, Panayi GS. Further observations on Klebsiella molecular cross-reactivity in HLA-B27 positive persons. J Rheumatol 1985;12:1024.

26 Geczy AF, Prendergast JK, McGuigan LE, Upfold LI, Sullivan JS. Cross-reactivity of anti-Klebsiella K43 BTS 1 serum and lymphocytes of patients with ankylosing spondylitis: antipodean curiosity? Lancet 1985;i:1169.

27 Beukelman CJ, van Leeuwen A, Aerts PC, van Kregten E, van Bree S, van Rood JJ, et al. Rabbit antisera to enterobacteriaceae isolated from HLA-B27 positive patients with ankylosing spondylitis (AS) are lytic for the mononuclea cells of AS patients. Br J Rheumatol 1988;27 (suppl 2):5860.

28 Baines M, Ebringer A, Avakian H, Samuel D, James DC. The use of enzyme immunoassay (EIA) and radiobinding assay to investigate the cross-reactivity of Klebsiella antigens and HLA B27 in ankylosing spondylitis patients antigens and HLA B27 in ankylosing spondylitis patients

29 Wakefield D, Easter J, Robinson P, Graham D, Penny R Chlamydial antibody crossreactivity with peripheral blood Chlamydial antibody crossreactivity with peripheral blood mononuclear cells of patients with ankylosing spondylitis:
the role of HLA B27. Clin Exp Immunol 1986;63:49-57.

30 Geczy AF, Yap J. HLA-B27, Klebsiella, and ankylosing spondylitis. Lancet 1979;i:719-20.

31 Seager K, Bashir HV, Geczy AF, Edmonds J, de VereTyndall A. Evidence for a specific B27-associated cell surface marker on lymphocytes of patients with ankylosing spondylitis. Nature 1979;277:68-70.

32 Geczy AF, Alexander K, Bashir HV, Edmonds J. A factor(s) in Klebsiella culture filtrates specifically modifies an HLAB27 associated cell-surface component. Nature 1980;283: 782-4.

33 Cameron FH, Russell PJ, Easter JF, Wakefield D, March L. Failure of Klebsiella pneumoniae antibodies to cross-react with peripheral blood mononuclear cells from patients with ankylosing spondylitis. Arthritis Rheum 1987;30:300-5.

34 Georgopoulos K, Dick WC, Goodacre JA, Pain RH. A reinvestigation of the cross-reactivity between Klebsiella and
HLA-B27 in the aetiology of ankylosing spondylitis. Clin Exp Immunol 1985;62:662-71.

35 Inman RD, Chiu B, Johnston ME, Falk J. Molecula mimicry in Reiter's syndrome: cytotoxicity and ELISA studies of HLA-microbial relationships. Immunology 1986;58:501-6.

36 Roudier J, De Montclos H, Thouvenot D, Chomel JJ, Guillermet FN, Betuel $\mathrm{H}$. Absence of cross-reaction between HLA B27 and yersinia enterocolitica or chlamydia trachomatis in reactive arthritis and ankylosing spondylitis. Clin Rheumatol 1985;4:487.

37 Geczy AF, McGuigan LE, Sullivan JS, Edmonds JP Cytotoxic $\mathrm{T}$ lymphocytes against disease-associated determinant(s) in ankylosing spondylitis. J Exp Med 1986;164 $932-7$

38 Gao XM, Wordsworth P, McMichael AJ, Kyaw MM, Seifert $M$, Rees D, et al. Homocysteine modification of HLA antigens and its immunological consequences. Eur J Immuno 1996;1443-50.

39 Archer JR, Whelan MA, Badakere SS, McLean IL, Archer IVJ, Winrow VR. Effect of a free sulphydryl group on expression of HLA-B27 specificity. Scand J Rheumatol 1990;87 (suppl):44-50.

40 van Bohemen CG, Grumet FC, Zanen HC. Identification of HLA-B27M1 and -M2 cross-reactive antigens in Klebsiella, Shigella and Yersinia. Immunology 1984;52:607-10 41 Raybourne RB, Bunning VK, Williams KM. Reaction of anti-HLA-B monoclonal antibodies with envelope proteins of Shigella species. Evidence for molecular mimicry in the spondyloarthropathies. J Immunol 1988;140:3489-95.

42 Kono DH, Ogasawara M, Effros RB, Park MS, Waldord RL, Yu DT. Ye-1, a monoclonal antibody that cross-reacts with HLA-B27 lymphoblastoid cell lines and an arthritis causing bacteria. Clin Exp Immunol 1985;61:503-8.

43 Feltkamp TEW. The mystery of autoimmune diseases. In Shoenfeld Y. ed. The decade of autoimmunity. Amsterdam: Elsevier Science BV, 1999.

44 Silverstein AM. A history of immunology. San Diego: Academic Press, 1989:161-89.

45 Berneman A, Ternynck T, Avrameas S. Natural mouse IgG reacts with self antigens including molecules involved in the immune response. Eur J Immunol 1992;22:625-33.

46 Cohen IR, Cooke A. Natural autoantibodies might prevent autoimmune disease. Immunol Today 1986;7:363-4.

47 Ivanyi P, Leupers T, van Mourik P. Naturally occurring cytotoxic human antibodies recognize $\mathrm{H}-2$ - controlled murine lymphocyte antigens. Proc Natl Acad Sci 1983;80 4479-83.

48 Avrameas S, Ternynck T. Natural autoantibodies: the other side of the immune system. Res Immunol 1995;146:23548.

49 Berneman A, Guilbert B, Eschrich S, Avrameas S. IgG auto- and polyreactivities of normal human sera. Mol Immunol 1993;30:1499-510.

50 Adib M, Ragimbeau J, Avrameas S, Ternynck T. IgG autoantibody activity in normal mouse serum is controlled autoantibody activity in normal mouse

51 Rose NR. The use of autoantibodies. In: Peter JB, Shoenfeld Y. eds. Autoantibodies. Amsterdam: Elsevier Science, 1996: xxvii-xxix.

52 Feltkamp TEW. Auto-immunziekten. Leiden: Stafleu's wetenschappelijke uitgeversmaatschappij nv, 1971:11-2.

53 Schwartz RS. Autoimmunity and autoimmune diseases. In Paul WE, ed. Fundamental immunology. New York: Raven Press, 1993:1033-97.

54 Talal N. Autoimmunity and sex reviseted. Clin Immunol Immunopathol 1989;53:355.

55 Singh B, Dillion T, Lauzon J, Fraga E, Russell AS. Tolerance to the HLA-B27 and Klebsiella pneumoniae crossreactive to the HLA-B27 and Klebsiella pneumoniae crossreactive epitope in mice transgenic for HLA-B2705
$\beta_{2}$-microglobulin. J Rheumatol 1994;21:670-4.

56 Handley HH, Yu J, Yu DT, Singh B, Gupta RS, Vaughan $\mathrm{JH}$. Autoantibodies to human heat shock protein (hsp) 60 may be induced by Escherichia coli groEL. Clin Exp Immunol 1996;103:429-35.

57 Juanola X, Mateo L, Domenech P, Bas J, Contreras N, Nolla JMXR-ED. Prevalence of antiphospholipid antibodies in patients with ankylosing spondylitis. J Rheumatol 1995;22 1891-3.

58 Vasey FB, Kinsella TD. Increased frequency of leukocytereactive antinuclear antibody in patients with ankylosing spondylitis. J Rheumatol 1977;4:158-64.

59 Kinsella TD, Miller J, Gofton JP, Vasey FB. Population studies of leukocyte-reactive antinuclear antibody and HLA antigens. Rheumatol Int 1981;1:103-5.

60 Tani Y, Sato H, Tanaka N, Mori K, Doida Y, Hukuda S. Serum IgA1 and IgA2 subclass antibodies against collagens in patients with ankylosing spondylitis. Scand J Rheumato 1997;26:380-2

61 Tani Y, Sato H, Hukuda S. Autoantibodies to collagens in Japanese patients with ankylosing spondylitis. Clin Exp Rheumatol 1997;15:295-7.

62 Lakomek HJ, Plomann M, Specker C, Schwochau M. Ankylosing spondylitis: an autoimmune disease? Ann Rheum Dis 1991;50:776-81.

63 Isenberg DA, Feldman R, Dudeney C, Konikoff F, Jones D, Ebringer AXSY. A study of antipolynucleotide antibodies, anti-Klebsiella (K30) antibodies and anti-DNA antibody idiotypes in ankylosing spondylitis. $\mathrm{Br} \mathrm{J}$ Rheumatol idiotypes in ankyl

64 Buchanan RR, Wardlaw JR, Riglar AG, Littlejohn GO, Miller MH. Antiphospholipid antibodies in the connective tissue diseases: their relation to the antiphospholipid syndrome and forme fruste disease. J Rheumatol 1989;16: 757-61.

65 MacSween RN, Dalakos TK, Jasani MK, Wilson ME, Boyle JA, Buchanan WWXGRB. Antinuclear factors in synovia fluids. Lancet 1967;i:312-14.

66 Pitkeathly DA, Taylor G. Antinuclear factor in rheumatoid arthritis and related diseases. Ann Rheum Dis 1967;26: $1-9$

67 Ritchie RF. The clinical significance of titered antinuclear antibodies. Arthritis Rheum 1967;10:544-52.

68 Rosenberg JN, Johnson GD, Holborow EJ. Antinuclear antibodies in ankylosing spondylitis, psoriatic arthritis, and antibodies in ankylosing spondylitis, psoriatic
psoriasis. Ann Rheum Dis 1979;38:526-8.

69 Wang JY, Yeh HY, Tu ST, Chen AC. Immunological study in three families of juvenile ankylosing spondylitis. Acta Paediatr Sin 1992;33:191-9.

70 Schwimmbeck PL, Yu DT, Oldstone MB. Autoantibodies to HLA B27 in the sera of HLA B27 patients with ankylosing spondylitis and Reiter's syndrome. Molecular mimicry with
Klebsiella pneumoniae as potential mechanism of autoimmune disease. J Exp Med 1987;166:173-81.

71 Schwimmbeck PL, Oldstone MB. Molecular mimicry between human leukocyte antigen B27 and Klebsiella. Consequences for spondyloarthropathies. Am J Med 1988; 85:51-3.

72 Tani Y, Tiwana H, Hukuda S, Nishioka J, Fielder M, Wilson C, et al. Antibodies to Klebsiella, Proteus, and HLA-B27 peptides in Japanese patients with ankylosing spondylitis and rheumatoid arthritis. J Rheumatol 1997;24:109-14. 
73 Fielder M, Pirt SJ, Tarpey I, Wilson C, Cunningham P, Ettelaie CXBA, et al. Molecular mimicry and ankylosing spondylitis: possible role of a novel sequence in pullulanas of Klebsiella pneumoniae. FEBS Lett 1995;369:243-8.

74 Tsuchiya N, Husby G, Williams RC Jr. Studies of humoral and cell-mediated immunity to peptides shared by HLA-27.1 and Klebsiella pneumoniae nitrogenase in ankylosing spondylitis. Clin Exp Immunol 1989;76:35460.

75 Tsuchiya N, Husby G, Williams RC Jr. Antibodies to the peptide from the plasmid-coded Yersinia outer membrane protein (YOP1) in patients with ankylosing spondylitis. protein (YOP1) in patients with

76 Cavender DE, Ziff M. Absence of Antienterobacteriaceae and anti-HLA-B27 antibodies in mitogen stimulated cultures of lymphocytes from patients with Reiter's cultures of lymphocytes from patients with Reiter's syndrome and

77 Ewing C, Ebringer R, Tribbick G, Geysen HM. Antibody activity in ankylosing spondylitis sera to two sites on HLA B27.1 at the MHC groove region (within sequence 65-85) and to a Klebsiella pneumoniae nitrogenase reductase peptide (within sequence 181-199). J Exp Med 1990;171: 1635-47

78 de Vries DD, Dekker-Saeys AJ, Gyodi E, Bohm U, Ivanyi P. Absence of autoantibodies to peptides shared by HLAB27.5 and Klebsiella pneumoniae nitrogenase in serum samples from HLA-B27 positive patients with ankylosing spondylitis and Reiter's syndrome. Ann Rheum Dis 1992;51:783-9.

79 Marker-Hermann E, Meyer zum Buschenfelde KH, Wildner G. HLA-B27-derived peptides as autoantigens for T ner G. HLA-B27-derived peptides as autoantigens for T lmphocytes in an

80 Kellner H, Wen J, Wang J, Raybourne RB, Williams KM, Yu DT. Serum antibodies from patients with ankylosin spondylitis and Reiter's syndrome are reactive with HLA-B27 cells transfected with the Mycobacterium tuberculosis hsp60 gene. Infect Immun 1994; 62:484-91.

81 Hermann E, Yu DT, Meyer zum Buschenfelde $\mathrm{KH}$ Fleischer B. HLA-B27-restricted CD8 T cells derived from synovial fluids of patients with reactive arthritis and ankylosing spondylitis. Lancet 1993;342:646-50.

82 Williams KM, Hirofuji T, Raybourne RB, Shook DL Trucksess MW, Yu DT. Synthetic oligonucleotide probes complementary to the HLA-B variable region hybridize with Klebsiella pneumoniae. Microb Pathogen 1989;6: with Kle

83 Winrow VR, Archer JR, Mitchell DJ. Regarding the ankylosing spondylitis/Klebsiella/HLA-B27 problem: more inconclusive proof. Arthritis Rheum 1988;31:453-4.

84 Tsuchiya N, Husby G, Williams RC Jr, Stieglitz H, Lipsky $\mathrm{PE}$, Inman RD. Autoantibodies to the HLA-B27 sequence cross-react with the hypothetical peptide from the arthritisassociated Shigella plasmid. J Clin Invest 1990;86:1193203.

85 Lahesmaa R, Skurnik M, Vaara M, Leirisalo-Repo M, Nissila M, Granfors K, et al. Molecular mimickry between HLA B27 and Yersinia, Salmonella, Shigella and Klebsiella within the same region of HLA alpha 1- helix. Clin Exp within the same region of 4 .

86 Stieglitz H, Lipsky P. Association between reactive arthritis and antecedent infection with Shigella flexneri carrying a 2-Md plasmid and encoding an HLA-B27 mimetic 2-Md plasmid and encoding an HLA-B2

87 Lahesmaa R, Skurnik M, Granfors K, Mottonen T, Saario $\mathrm{R}$, Toivanen AXTP. Molecular mimicry in the pathogenesis of spondyloarthropathies. A critical appraisal of crossreactivity between microbial antigens and HLA-B27. Br Rheumatol 1992;31:221-9.
88 Ohno S. Many peptide fragments of alien antigens are homologous with host proteins, thus canalizing T-cell responses. Proc Natl Acad Sci 1991;88:3065-8

89 Roudier C, Auger I, Roudier J. Molecular mimicry reflected through database screening: serendipity or survival strategy? Immunol Today 1996;17:357-8.

90 Kalovidouris AE, Johnson RL. Cellular immunity in ankylosing spondylitis. Lack of response to spinal tissue antigens. J Rheumatol 1983;10:98-101.

91 Thonar EJ, Sweet MB. Cellular hypersensitivity in rheumatoid arthritis, ankylosing spondylitis, and anterior nontoid arthritis, ankylosing spondylitis, and anterior non-

92 Sranulomatous uveitis. Arthritis Rheum 1976;19:539-44. veld FC. IgG and IgA autoantibodies to C1q in systemic and renal diseases. Clin Exp Rheumatol 1992;10:19-23.

93 Austin AK, Hobbs RN, Anderson JC, Butler RC, Ashton BA. Humoral immunity to link protein in patients with inflammatory joint disease, osteoarthritis, and in nonarthritic controls. Ann Rheum Dis 1988;47:886-92.

94 Stuart JM, Postlethwaite AE, Townes AS, Kang AH. Cell-mediated immunity to collagen and collagen alpha chains in rheumatoid arthritis and other rheumatic chains in rheumatoid arthritis and

95 Smolen JS, Menzel EJ, Scherak O, Kojer M, Kolarz G, Steffen $\mathrm{C}$, et al. Lymphocyte transformation to denatured type I collagen and B lymphocyte alloantigens in rheumatoid arthritis. Arthritis Rheum 1980;23:424-31.

96 Clague RB, Shaw MJ, Holt PJ. Incidence of serum antibodies to native type I and type II collagens in patients with inflammatory arthritis. Ann Rheum Dis 1980;39:201-6.

97 Clague RB, Shaw MJ, Holt PJ. Incidence and correlation between serum IgG and IgM antibodies to native type II collagen in patients with chronic inflammatory arthritis. Ann Rheum Dis 1981;40:6-10.

98 Rosenberg AM, Hunt DW, Petty RE. Antibodies to native and denatured type II collagen in children with rheumatic and denatured type II collagen in child
diseases. J Rheumatol 1984;11:425-31.

99 Gao XM, Wordsworth P, McMichael A. Collagen-specific cytotoxic $\mathrm{T}$ lymphocyte responses in patients with ankylosing spondylitis and reactive arthritis. Eur J Immunol 1994 24:1665-70.

100 Borg AA, Nixon NB, Dawes PT, Mattey DL. Increased IgA antibodies to cytokeratins in the spondyloarthropathies. Ann Rheum Dis 1994;53:391-5.

101 Locht H, Peen E, Skogh T. Antineutrophil cytoplasmic antibodies in reactive arthritis. J Rheumatol 1995;22: $2304-6$.

102 De Keyser F, Mielants H, Praet J, Goemaere S, Veys EM. Changes in antinuclear serology in patients with spondylar-
thropathy under sulphasalazine treatment. Br J Rheumatol thropathy under

103 Saraux A, de Saint Pierre V, Baron D, Valls I, Koreichi A Youinou PXLGP. The antiperinuclear factor in spondylarthropathies. Br J Rheumatol 1995;34:912-14

104 Sondag-Tschroots IR, Aaij C, Smit JW, Feltkamp TE. The antiperinuclear factor. 1 . The diagnostic significance of the antiperinuclear factor for rheumatoid arthritis. Ann Rheum Dis 1979;38:248-51.

105 Youinou P, Le Goff P, Dumay A, Lelong A, Fauquert PXJJ The antiperinuclear factor. I. Clinical and serologic associations. Clin Exp Rheumatol 1990;8:259-64.

106 MacSween RN, Goudie RB, Anderson JR, Armstrong E, Murray MA, Mason DKXIM, et al. Occurrence of Murray MA, Mason DKXJM, et al. Occurrence of antibody to salivary duct epithelium in Sjogren's disease, laboratory study. Ann Rheum Dis 1967;26:402-11.

107 Blake DR, McGregor AM, Stansfield E, Smith BR. Antithyroid-antibody activity in the snyovial fluid of patients with various arthritides. Lancet 1979;ii:224-6. 